Conclusion Our results showed that the mean survival time for CRC depends on some risk factors. It seems that, evaluation of these risk factors is necessary in lower age.

\section{SP6-27 THE EFFECT CLINICAL PATHWAYS IN LENGTH OF STAY, DRUG USAGE AND CHARGE PER CASE IN INDONESIAN HOSPITALS: A QUASI EXPERIMENTAL}

doi:10.1136/jech.2011.142976p.98

F L P Sitorus, J Atthobari, ${ }^{*}$ T Kuncoro, L Trisnantoro. Faculty of Medicine, Gadjah Mada University, Yogyakarta, Indonesia

Introduction Clinical pathways (CP) are proven as tool for increasing hospital care efficiency and quality. The Indonesian's government implemented Indonesian Diagnostic Related-Groups (INA-DRGs) based on casemix system; therefore, CP becomes an important tool in reducing hospital costs.

Objective Assessing the effect of CPs implementation in reducing the average length of stay (ALOS) and charge per-case, and increasing use of generic antibiotic.

Method This study was a quasi experimental. The CP was implemented on May 2008 in Djasamen Saragih District Hospital (DSDH) at Pematangsiantar City, North Sumatera. Pirngadi General Hospital (PGH) at Medan, North Sumatera, was acted as control hospital. Total 254 appendectomy cases were analysed, which were consisted 124 cases in DSDH (pre 60 and post 64) and 130 cases in PGH (pre 60 and post 70). The study outcomes were measured 12 months before and after CP implementation and compared between two hospitals.

Result The subject's characteristics were not significant difference between two groups. The ALOS was significantly reduced from $5.2 \pm 1.1$ days before intervention to $4.8 \pm 0.9$ after intervention in $\mathrm{DSDH}$, while in control hospital no difference in reducing ALOS $(4.9 \pm 1.2$ to $4.7 \pm 1.1)$. The use of generic antibiotics per-case were raised from $1.5 \pm 0.8$ to $1.9 \pm 0.7$ in $\mathrm{DSDH}$, while in control reduced from $2.0 \pm 0.9$ to $1.9 \pm 1.0$. The charge per case was not significantly reduced in intervention, nor control hospital.

Conclusion Clinical pathways trends to improve hospital ALOS, generic use of antibiotics and charge per case, therefore, the CP may effective method to increase efficiency in hospital care.

\section{SP6-28 EFFECT OF UMBILICAL CORD BLOOD ACID-BASE STATUS AND GAS VALUES ON THE YIELD OF MONONUCLEAR CELLS AND CD34 CELLS}

doi:10.1136/jech.2011.142976p.99

${ }^{1} \mathrm{~S} S$ Ebina, ${ }^{*} \mathrm{~A}$ Omori, ${ }^{2} \mathrm{~A}$ Tarakida, ${ }^{2} \mathrm{~T}$ Ogasawara, ${ }^{2} \mathrm{M}$ Manabe, ${ }^{2} \mathrm{~S}$ I Katagiri, ${ }^{1}$ I Kashiwakura. ${ }^{1}$ Hirosaki University Graduate School of Health Sciences, Hirosak, Aomori, Japan; ${ }^{2}$ Hirosaki National Hospital, Hirosak, Aomori, Japan

Purpose To investigate the influence of umbilical cord blood (CB) acid-base status and gas values on the yield of mononuclear cells and $\mathrm{CD} 34$ cells, $\mathrm{pH}, \mathrm{pCO}_{2}, \mathrm{pO}_{2}, \mathrm{HCO}_{3}{ }^{-}$and base excess were measured in arterial $\mathrm{CB}$ samples obtained from normal full-term deliveries. The relationship of these values with the yield of mononuclear cells and CD34 cells detected in venous CB was analysed.
Methods A total of 145 CB units were collected from full-term vaginal deliveries at a single hospital. Immediately after delivery, a segment of the umbilical cord was double clamped, and arterial CB was analysed to determine the acid-base status and gases. Venous $\mathrm{CB}$ was collected into a sterile collection bag and processed for cell separation within $24 \mathrm{~h}$ collection. The relationship between umbilical arterial acid-base status, each gas value, and the yield of mononuclear cells and CD34 cells was analysed.

Results Statistically significant correlations were observed between the net weight of $\mathrm{CB}$ and the total mononuclear and CD34 cell counts. In addition, there was a negative correlation between the mononuclear cell counts and $\mathrm{pH}$, but a positive correlation between the mononuclear cell counts and $\mathrm{pCO}_{2}$. However, no significant differences were observed between the nulliparous and multiparous groups in terms of the net weight of $\mathrm{CB}$, total mononuclear cell counts and total CD34 cell counts.

Conclusions The findings of the present study show that the mononuclear cell counts are correlated with arterial $\mathrm{CB} p \mathrm{pH}$ and $\mathrm{pCO}_{2}$, suggesting the involvement of fetal hypoxia on the yield of mononuclear cells.

\section{SP6-29 HOMEMAKERS' PRACTICES AND PERCEPTIONS: RISK FACTORS FOR CHILDHOOD DISEASE IN AN UNDERSERVED COMMUNITY IN LEBANON}

doi:10.1136/jech.2011.142976p.100

R R Habib, ${ }^{*}$ S Hojeij, G El Azar. American University of Beirut, Beirut, Lebanon

Introduction Diarrhoea presents a global health problem and a leading cause of morbidity and mortality in developing countries. Over the decades, the rate of morbidity due to diarrhoea among children has not changed considerably. Contaminated water, inadequate sanitation and poor hygiene remain the most predominant risk factors for this disease. Our study evaluated the prevalence of childhood diarrhoea and risk factors associated with the illness in a disadvantaged community of more than 15000 people in Lebanon. Methods The study utilised a random cross-sectional design and structured questionnaire with women homemakers, and included data on 460 children aged 5 years old or younger. Data on sociodemographic variables, 4-week diarrhoeal prevalence, and indicators of potential risk factors affecting the incidence of diarrhoea were collected. A multiple logistic regression analysis identified the associations between these indicators and diarrhoeal prevalence.

Results The findings showed that $21 \%$ of children experienced a diarrhoeal episode in the past 4 weeks. Children, who were not breastfed, walked barefoot, and whose mother perceives diarrhoea as non-preventable were more likely to suffer from diarrhoea.

Conclusion Based on the study findings, a strategy to reduce childhood diarrhoea might include community awareness programs promoting breastfeeding and childcare practices and improve personal and domestic hygiene conditions. It is also valuable to carry out research on the social determinants of childhood diarrhoea, which could inform relevant interventions in the local context. The combination of these strategies in turn will guide the design of contextually relevant and effective community-based programs that reduce diarrhoea. 